Erhard Meyer-Galow

Business Ethics 3.0 



\section{Erhard Meyer-Galow}

\section{Business \\ Ethics 3.0}

The New Integral Ethics from the Perspective of a CEO 
Erhard Meyer-Galow

www.business-ethics-3.com

ISBN 978-3-11-057228-5

e-ISBN (PDF) 978-3-11-057229-2

e-ISBN (EPUB) 978-3-11-057242-1

Library of Congress Control Number: 2018934554

Bibliographic information published by the Deutsche Nationalbibliothek The Deutsche Nationalbibliothek lists this publication in the Deutsche Nationalbibliografie; detailed bibliographic data are available on the Internet at http://dnb.dnb.de.

(C) 2018 Walter de Gruyter GmbH, Berlin/Boston

Cover illustration: Erhard Meyer-Galow Typestting: Integra Software Services Pvt. Ltd. Assistant Editor: Richard Warrington Printing and binding: CPI books $\mathrm{GmbH}$, Leck

www.degruyter.com 
Business Ethics 3.0, by Erhard Meyer-Galow provides a much needed beacon of light to a segment of our society that seem to be sinking deeper and deeper into darkness. The term "business ethics", once an important topic within the business community, has slowly descended through the fog of profitable ends justifying unprincipled means to become nothing more than a self-contradictory oxymoron - especially among large international corporations. In Business Ethics 3.0, Erhard Meyer-Galow has taken a fresh approach that appeals to individual personal growth rather than the usual proffering of academic arguments that are not implementable in the real world of relentless Machiavellian competition. Only through raising and improving individual awareness and responsibility can real long-term change have a chance of developing. Business Ethics 3.0 is on the right track with a positive and compelling message...may it succeed where the academics have failed.

- Thomas Campbell, physicist, consciousness researcher, author of My big TOE 
